\title{
Role of IL-10 gene polymorphisms in the development of acute pancreatitis
}

\author{
B.Z. Jiang, L. Tang, H. Xue and D.P. Liu \\ Internal Medicine of Emergency Department, \\ Shaanxi Provincial People's Hospital, Xi'an, China \\ Corresponding author: D.P. Liu \\ E-mail: danpingliua@163.com \\ Genet. Mol. Res. 15 (2): gmr.15027743 \\ Received September 29, 2015 \\ Accepted December 28, 2015 \\ Published May 6, 2016 \\ DOI http://dx.doi.org/10.4238/gmr.15027743
}

\begin{abstract}
Recent studies have suggested that chemokines contribute to the initiation and development of acute pancreatitis. We evaluated the relationship between $I L-10$ gene polymorphisms (-1082A/G and -819T/ C) and development of acute pancreatitis in the Chinese population, in order to provide data for screening high-risk Chinese individuals. In total, 182 patients with confirmed cases of acute pancreatitis and 262 control subjects were recruited from the Shaanxi Provincial People's Hospital between April 2012 and December 2014. IL-10 gene polymorphisms at positions $-1082 \mathrm{~A} / \mathrm{G}$ and $-819 \mathrm{~T} / \mathrm{C}$ were examined using the polymerase chain reaction-restriction fragment length polymorphism method. Through multiple-logistic regression analysis, the GG genotype in $I L-10-1082 \mathrm{~A} / \mathrm{G}$ could influence the susceptibility to acute pancreatitis compared to the AA genotype, and the adjusted OR $(95 \% \mathrm{CI})$ was $2.68(1.34-5.39)(\mathrm{P}=0.002)$. Individuals who carried the $\mathrm{AG}+\mathrm{GG}$ genotype of $I L-10-1082 \mathrm{~A} / \mathrm{G}$ were associated with greater risk for acute pancreatitis compared to the wide-type genotype, and the adjusted OR (95\%CI) was 1.64 (1.09-2.46). However, no significant difference in susceptibility to acute pancreatitis was found between the IL-10 gene polymorphism at $-819 \mathrm{~T} / \mathrm{C}$. In conclusion, this study
\end{abstract}


demonstrates that the $I L-10-1082 \mathrm{~A} / \mathrm{G}$ gene polymorphism contributes to the development of acute pancreatitis.

Key words: Interleukin-10; -1082A/G; -819T/; Polymorphism; Acute pancreatitis

\section{INTRODUCTION}

Acute pancreatitis is a sudden inflammation of the pancreas and a serious disease worldwide (Banks et al., 2006; Pandol et al., 2007). The pathophysiology of this disease includes edema, hemorrhage, and necrosis (Gorelick and Thrower, 2009). Previous studies have reported that approximately $35 \%$ of acute pancreatitis patients develop severe complications, resulting in high mortality rates (Neoptolemos et al., 1998; Lankisch et al., 2003; Swaroop et al., 2004). Acute pancreatitis is a complex disease, and the accurate mechanisms underlying its development are not well understood. It has been suggested that many lifestyle choices and environmental factors such as excessive drinking, pancreatic duct strictures, viral or bacterial infection, hyperlipidemia, metabolic disorders, and infections are associated with disease susceptibility (Álvarez et al., 2015; Greer et al., 2015; Pohl and Uc, 2015; Talukdar and Vege, 2015; Tun-Abraham et al., 2015). Recent studies have reported that genetic factors play an important role in the pathogenesis of acute pancreatitis, such as interleukin-1 $\beta(I L-1 \beta), I L-8$, $I L-10$, heme oxygenase-1 gene, Toll-like receptor gene, tumor necrosis factor alpha gene, and heat-shock protein 70-2 gene (Özhan et al., 2010; Bishehsari et al., 2012; Srivastava et al., 2012; Gulla et al., 2014; Li et al., 2015; Matas-Cobos et al., 2015).

Recent studies have suggested that chemokines contribute to the initiation and development of acute pancreatitis, and are involved in systemic inflammatory response syndrome and multiple-organ dysfunction syndrome (Sun and Bhatia, 2007). IL-10 is an immune-regulatory cytokine produced by Th2 cells, regulatory $\mathrm{T}$ cells, and monocytes/ macrophages. Currently, few studies have explored the role of $I L-10$ gene polymorphisms in the acute pancreatitis risk (Yin et al., 2013). Here we evaluated the relationship between $I L-10$ gene polymorphisms $(-1082 \mathrm{~A} / \mathrm{G}$ and $-819 \mathrm{~T} / \mathrm{C})$ and development of acute pancreatitis in the Chinese population, in order to provide data for screening high-risk Chinese individuals.

\section{MATERIAL AND METHODS}

\section{Study subjects}

A total of 182 patients were consecutively recruited from the Shaanxi Provincial People's Hospital between April 2012 and December 2014. The diagnosis of acute pancreatitis was based on the following criteria: self-reported abdominal pains or other clinical symptoms in the abdomen, demonstrated features of acute pancreatitis on computed tomography scans, and three times the normal level of serum amylases. Patients who had a history of serious liver and kidney diseases, acute and chronic infection disease, and malignant tumors were excluded from the study. Healthy subjects (262) were also recruited from the Shaanxi Provincial People's Hospital at the same time, and served as controls. All individuals in the control group were free of acute pancreatitis, malignant tumors, chronic and acute infection diseases, digestive system disease, and serious liver or kidney diseases. 
The average ages of acute pancreatitis patients were $64.70 \pm 10.42$ years. In acute pancreatitis patients, $60(32.97 \%)$ subjects were females, $122(67.03 \%)$ were males, 68 $(37.36 \%)$ were smokers, and $109(59.89 \%)$ were drinkers. In control subjects, the mean age was $66.31 \pm 9.65$ years, $122(46.56 \%)$ were females, $140(53.44 \%)$ were males, $90(34.35 \%)$ were smokers, and $114(43.51 \%)$ were drinkers.

Information regarding the demographics and lifestyle choices of acute pancreatitis patients and control subjects was enrolled through self-designed questionnaires or medical records. Detailed clinical information including age, gender, body mass index (BMI), alcohol consumption, tobacco smoking, and family history was recorded. Blood samples $(5 \mathrm{~mL})$ and signed informed consent forms were obtained from each subject before enrollment. The methodology of this study was reviewed by the Ethics Board Committee of the Shaanxi Provincial People's Hospital.

\section{DNA isolation}

Peripheral venous blood samples were collected in ethylenediaminetetraacetic acid tubes, and stored at $-20^{\circ} \mathrm{C}$ until use. Genomic DNA was extracted from the blood samples using QIAamp DNA Blood Mini Kit (QIAGEN, USA) following the manufacturer's recommendation. Genotyping of the $I L-10-1082 \mathrm{~A} / \mathrm{G}$ and $-819 \mathrm{~T} / \mathrm{C}$ gene polymorphisms was carried out via polymerase chain reaction-restriction fragment length polymorphism (PCR-RFLP). The forward and reverse primer sequences for genotyping IL-10 -1082A/G were 5'-GTGGAAGAAGTCCTGAGTCCACTG-3' and 5'-ACTTTCATCCСТTATTCCCTACTTCC-3', respectively. The forward and reverse primers for IL-10 -819T/C were 5'-GCTTCTTAATTGCTAGTCACCTA-3' and 5'-TGTCGGAAGTGGCTAAGAGT-3', respectively. The identities of restriction enzymes used for DNA digestion of $I L-10-1082 \mathrm{~A} / \mathrm{G}$ and $-819 \mathrm{~T} / \mathrm{C}$ were $M n I I$ and $M s I I$, respectively. The lengths of digested fragment for $I L-10-1082 \mathrm{~A} / \mathrm{G}$ and $-819 \mathrm{~T} / \mathrm{C}$ were 139 and $209 \mathrm{bp}$, respectively. DNA PCR was set at: $95^{\circ} \mathrm{C}$ for $2 \mathrm{~min}$, followed by 35 cycles of $94^{\circ} \mathrm{C}$ for $30 \mathrm{~s}$, $65^{\circ} \mathrm{C}$ for $30 \mathrm{~s}$ and $72^{\circ} \mathrm{C}$ for $45 \mathrm{~s}$, and a final elongation of $7 \mathrm{~min}$ at $72^{\circ} \mathrm{C}$. The DNA fragments were stained with ethidium bromide on $2 \%$ agarose gel, and visualized under ultraviolet light.

\section{Statistical analysis}

The statistical variation within the demographic and lifestyle data of the two study groups was carried out using the chi-square test ( $\chi^{2}$ test) for the categorical data. The $\chi^{2}$ goodness-of-fit test was conducted to determine whether genotype distribution in the study subjects followed Hardy-Weinberg equilibrium (HWE). Unconditional logistic regression analysis was used to determine the association between $I L-10-1082 \mathrm{~A} / \mathrm{G}$ and $-819 \mathrm{~T} / \mathrm{C}$ gene polymorphisms and acute pancreatitis development. Adjusted odds ratio (OR) and associated 95\% confidence intervals (CIs) were calculated for assessment of statistical significance. The SPSS 20.0 software (SPSS Inc., Chicago, IL, USA) was used to carry out the statistical analysis. $P$ values $<0.05$ were considered to be statistically significant.

\section{RESULTS}

The demographics and lifestyles of patients with acute pancreatitis and control subjects are summarized in Table 1 . The two groups were compared in terms of age $\left(\chi^{2}=0.37\right.$, 
$\mathrm{P}=0.54)$, family history of acute pancreatitis $\left(\chi^{2}=3.38, \mathrm{P}=0.07\right)$, and tobacco smoking $\left(\chi^{2}\right.$ $=0.42, \mathrm{P}=0.51)$. There were significant differences between patients with acute pancreatitis and control subjects with respect to gender $\left(\chi^{2}=8.21, \mathrm{P}=0.004\right)$, BMI $\left(\chi^{2}=27.38, \mathrm{P}=0.004\right)$ and alcohol consumption $\left(\chi^{2}=11.52, \mathrm{P}<0.001\right)$.

Table 1. Demographic and lifestyle characteristics between acute pancreatitis patients and control subjects.

\begin{tabular}{|c|c|c|c|c|c|c|}
\hline Variables & Patients & $\%$ & Controls & $\%$ & $\chi^{2}$ test & $\mathrm{P}$ value \\
\hline \multicolumn{7}{|l|}{ Gender } \\
\hline Female & 60 & 32.97 & 122 & 46.56 & & \\
\hline Male & 122 & 67.03 & 140 & 53.44 & 8.21 & 0.004 \\
\hline \multicolumn{7}{|c|}{ Age (years) } \\
\hline$\leq 60$ & 57 & 31.32 & 75 & 28.63 & & \\
\hline$>60$ & 125 & 68.68 & 187 & 71.37 & 0.37 & 0.54 \\
\hline \multicolumn{7}{|c|}{ Family history } \\
\hline No & 163 & 89.56 & 247 & 94.27 & & \\
\hline Yes & 19 & 10.44 & 15 & 5.73 & 3.38 & 0.07 \\
\hline \multicolumn{7}{|l|}{ BMI } \\
\hline$\leq 25$ & 79 & 43.41 & 179 & 68.32 & & \\
\hline$>25$ & 103 & 56.59 & 83 & 31.68 & 27.38 & $<0.001$ \\
\hline \multicolumn{7}{|c|}{ Tobacco smoking } \\
\hline No & 114 & 62.64 & 172 & 65.65 & & \\
\hline Yes & 68 & 37.36 & 90 & 34.35 & 0.42 & 0.51 \\
\hline \multicolumn{7}{|c|}{ Alcohol consumption } \\
\hline No & 73 & 40.11 & 148 & 56.49 & & \\
\hline Yes & 109 & 59.89 & 114 & 43.51 & 11.52 & $<0.001$ \\
\hline
\end{tabular}

The genotype distributions of $I L-10-1082 \mathrm{~A} / \mathrm{G}$ and $-819 \mathrm{~T} / \mathrm{C}$ in the two study groups are described in Table 2. In patients with acute pancreatitis, $69(37.92 \%), 85(46.70 \%)$, and $28(15.38 \%)$ cases carried the AA, AG, and GG genotypes of $I L-10-1082 \mathrm{~A} / \mathrm{G}$, respectively, and $63(34.62 \%), 84(46.15 \%)$, and $35(19.23 \%)$ cases carried the TT, TC, and CC genotypes of $I L-10-819 \mathrm{~T} / \mathrm{C}$, respectively. In control subjects, $130(49.62 \%), 112(42.75 \%)$, and 20 (7.63\%) cases carried the AA, AG, and GG genotypes of $I L-10-1082 \mathrm{~A} / \mathrm{G}$, respectively, and 99 (37.79\%), $112(42.75 \%)$, and 51 (19.47\%) cases carried the TT, TC, and CC genotypes of $I L-10-819 \mathrm{~T} / \mathrm{C}$, respectively. In both acute pancreatitis patients and control subjects, genotype frequencies of IL-10 $-1082 \mathrm{~A} / \mathrm{G}$ and $-819 \mathrm{~T} / \mathrm{C}$ were confirmed to be at HWE (all P values $>0.05$ ). There were significant differences in the genotype distributions of $I L-10-1082 \mathrm{~A} / \mathrm{G}$ between patients with acute pancreatitis and control subjects $\left(\chi^{2}=9.97, \mathrm{P}=0.007\right)$. However, the genotype distributions of $I L-10-819 \mathrm{~T} / \mathrm{C}$ were comparable between the two study groups $\left(\chi^{2}=0.58, \mathrm{P}=0.75\right)$.

Through unconditional logistic regression analysis, the GG genotype in $I L-10$ $-1082 \mathrm{~A} / \mathrm{G}$ could influence the susceptibility to acute pancreatitis compared to the AA genotype, and the adjusted OR $(95 \% \mathrm{CI})$ was 2.68 (1.34-5.39) $(\mathrm{P}=0.002$; Table 3). Individuals who carried the $\mathrm{AG}+\mathrm{GG}$ genotype of $I L-10-1082 \mathrm{~A} / \mathrm{G}$ were associated with greater risk for acute pancreatitis compared to the wide-type genotype, and the adjusted OR $(95 \% \mathrm{CI})$ was $1.64(1.09-2.46)(\mathrm{P}=0.01)$. However, the unconditional logistic regression analysis revealed that the $I L-10-819 \mathrm{~T} / \mathrm{C}$ gene polymorphism could not influence the risk of acute pancreatitis. 
Table 2. Genotype distributions of $I L-10-1082 \mathrm{~A} / \mathrm{G}$ and $-819 \mathrm{~T} / \mathrm{C}$ gene polymorphisms in acute pancreatitis patients and controls.

\begin{tabular}{|c|c|c|c|c|c|c|c|c|}
\hline \multirow[t]{2}{*}{ IL-10 } & \multirow[t]{2}{*}{ Patients $(\mathrm{N}=182)$} & \multirow[t]{2}{*}{$\%$} & \multirow[t]{2}{*}{ Controls $(\mathrm{N}=262)$} & \multirow[t]{2}{*}{$\%$} & \multicolumn{2}{|c|}{ P value for HWE } & \multirow[t]{2}{*}{$\chi^{2}$ test } & \multirow[t]{2}{*}{$P$ value } \\
\hline & & & & & Cases & Controls & & \\
\hline \multicolumn{9}{|l|}{$-1082 \mathrm{~A} / \mathrm{G}$} \\
\hline $\mathrm{AA}$ & 69 & 37.92 & 130 & 49.62 & & & & \\
\hline $\mathrm{AG}$ & 85 & 46.70 & 112 & 42.75 & & & & \\
\hline GG & 28 & 15.38 & 20 & 7.63 & 0.87 & 0.54 & 9.97 & 0.007 \\
\hline \multicolumn{9}{|l|}{$-819 \mathrm{~T} / \mathrm{C}$} \\
\hline TT & 63 & 34.62 & 99 & 37.79 & & & & \\
\hline TC & 84 & 46.15 & 112 & 42.75 & & & & \\
\hline $\mathrm{CC}$ & 35 & 19.23 & 51 & 19.47 & 0.46 & 0.06 & 0.58 & 0.75 \\
\hline
\end{tabular}

Table 3. Association between $I L-10-1082 \mathrm{~A} / \mathrm{G}$ and $-819 \mathrm{~T} / \mathrm{C}$ gene polymorphisms and development of acute pancreatitis.

\begin{tabular}{l|c|c|c|c|c|c}
\hline IL-10 & Patients & $\%$ & Controls & $\%$ & OR (95\%CI) & P value \\
\hline$-1082 \mathrm{~A} / \mathrm{G}$ & & & & & & \\
\hline $\mathrm{AA}$ & 69 & 37.92 & 130 & 49.62 & 1.0 (Reference) & - \\
\hline $\mathrm{AG}$ & 85 & 46.70 & 112 & 42.75 & $1.45(0.95-2.23)$ & 0.07 \\
\hline $\mathrm{GG}$ & 28 & 15.38 & 20 & 7.63 & $2.68(1.34-5.39)$ & 0.002 \\
\hline $\mathrm{AG}+\mathrm{GG}$ & 113 & 62.09 & 132 & 50.38 & $1.64(1.09-2.46)$ & 0.01 \\
\hline$-819 \mathrm{~T} / \mathrm{C}$ & & & & & & \\
\hline TT & 63 & 34.62 & 99 & 37.79 & 1.0 (Reference) & - \\
\hline TC & 84 & 46.15 & 112 & 42.75 & $1.18(0.75-1.84)$ & 0.45 \\
\hline CC & 35 & 19.23 & 51 & 19.47 & $1.08(0.61-1.90)$ & 0.78 \\
\hline TC+CC & 119 & 65.38 & 163 & 62.21 & $1.15(0.76-1.74)$ & 0.49 \\
\hline
\end{tabular}

${ }^{1}$ Adjusted for gender, age, BMI, and drinking status.

\section{DISCUSSION}

Single nucleotide polymorphism (SNP) is defined as the insertion, deletion, or replacement of a single nucleotide base in a gene sequence (Friedberg, 2003). SNPs in the cytokine genes could alter expression, structure, as well as the level of proteins produced, which in turn affects gene function (Aas et al., 2003; Bartek and Lukas, 2003). In this study, we evaluated the genotype distributions of two functional SNPs in the IL-10 gene, and their roles in the development of acute pancreatitis. We found that the GG genotype of IL-10 -1082A/G and the $\mathrm{AG}+\mathrm{GG}$ genotypes of IL-10 $-1082 \mathrm{~A} / \mathrm{G}$ were correlated with greater risk for acute pancreatitis, when compared to the AA genotype.

Many studies have reported an association between the $I L-10$ gene polymorphism and the development of inflammation-related diseases such systemic lupus erythematosus, coronary artery disease, peptic ulcer disease, Behçet's disease, lupus nephritis, and leprosy (Cheng et al., 2010; da Silva et al., 2014; Al-Okaily et al., 2015; Alvarado-Arnez et al., 2015; Krasnova et al., 2015; Yang et al., 2015). Cheng et al. (2010) reported that $I L-10-819 \mathrm{~T} / \mathrm{C}$ and $-592 \mathrm{~A} / \mathrm{C}$ genetic polymorphisms are associated with an increased risk of erosive reflux esophagitis and gastritis. da Silva et al. (2014) have conducted a study in the Brazilian population, and they have reported that IL-10 genetic polymorphism contributes to the development of systemic lupus erythematosus. Al-Okaily et al. (2015) carried out a study with 272 Saudi subjects, and suggest that $I L-10-1082 \mathrm{~A} / \mathrm{G},-819 \mathrm{~T} / \mathrm{C}$, and $-592 \mathrm{~A} / \mathrm{C}$ genetic variations are associated with the risk of Behçet's disease. Alvarado-Arnez et al. (2015) conducted a meta-analysis study, 
and have reported that $I L-10-819 \mathrm{~T} / \mathrm{C}$ is associated with leprosy susceptibility. Krasnova et al. (2015) have suggested that the IL-10 gene polymorphism is associated with the severe course of the disease. Yang et al. (2015) suggested that the $I L-10-1082 \mathrm{~A} / \mathrm{G}$ polymorphism is involved in the pathogenesis of coronary artery disease. These studies suggest that $I L-10$ gene polymorphisms likely contribute to the susceptibility to inflammation-related diseases.

Correlations between the IL-10 gene polymorphism and the development of acute pancreatitis have been investigated in several studies, and the results were inconclusive (Sargen et al., 2000; Schneider et al., 2004a,b; Zhang et al., 2005; de-Madaria et al., 2008; Bao et al., 2015; Li et al., 2015). Zhang et al. (2005) conducted a study in a Chinese population, and they reported that the $I L-10-1082 \mathrm{~A} / \mathrm{G}$ gene polymorphism plays an important role in the susceptibility of acute severe pancreatitis. However, the other six studies did not reveal a significant association between IL-10 genetic polymorphisms and development of acute pancreatitis. In our study, we indicated that the $I L-10-1082 \mathrm{~A} / \mathrm{G}$ genetic variation contributes to acute pancreatitis risk. The discrepancies among previous studies may be due to differences in the population assessed, sample sizes, and patient/control selection.

To sum up, this study demonstrates that the $I L-10-1082 \mathrm{~A} / \mathrm{G}$ gene polymorphism contributes to the development of acute pancreatitis. Further genetic and functional investigations are required to elucidate the mechanisms of the L-10 -1082A/G gene and acute pancreatitis.

\section{Conflicts of interest}

The authors declare no conflict of interest.

\section{ACKNOWLEDGMENTS}

We thank the study subjects for donating their blood samples for analysis.

\section{REFERENCES}

Aas PA, Otterlei M, Falnes PO, Vågbø CB, et al. (2003). Human and bacterial oxidative demethylases repair alkylation damage in both RNA and DNA. Nature 421: 859-863.http://dx.doi.org/10.1038/nature01363

Al-Okaily F, Arfin M, Al-Rashidi S, Al-Balawi M, et al. (2015). Inflammation-related cytokine gene polymorphisms in Behçet's disease. J. Inflamm. Res. 8: 173-180.

Alvarado-Arnez LE, Amaral EP, Sales-Marques C, Durães SM, et al. (2015). Association of IL10 Polymorphisms and Leprosy: A Meta-Analysis. PLoS One 10: e0136282. http://dx.doi.org/10.1371/journal.pone.0136282

Álvarez J, Castro P, Fernández M, Mcmullen B, et al. (2015). Clinical and radiological indicators of severity in patients with acute pancreatitis. Bol. Asoc. Med. P. R. 107: 33-37.

Banks PA and Freeman ML; Practice Parameters Committee of the American College of Gastroenterology (2006). Practice guidelines in acute pancreatitis. Am. J. Gastroenterol. 101: 2379-2400. http://dx.doi.org/10.1111/j.1572$\underline{0241.2006 .00856 . x}$

Bao XB, Ma Z, Gu JB, Wang XQ, et al. (2015). IL-8 -251T/A polymorphism is associated with susceptibility to acute pancreatitis. Genet. Mol. Res. 14: 1508-1514.http://dx.doi.org/10.4238/2015.February.20.6

Bartek J and Lukas J (2003). DNA repair: Damage alert. Nature 421: 486-488. http://dx.doi.org/10.1038/421486a

Bishehsari F, Sharma A, Stello K, Toth C, et al. (2012). TNF-alpha gene (TNFA) variants increase risk for multi-organ dysfunction syndrome (MODS) in acute pancreatitis. Pancreatology 12: 113-118. http://dx.doi.org/10.1016/j. pan.2012.02.014

Cheng HH, Chang CS, Wang HJ and Wang WC (2010). Interleukin-1beta and -10 polymorphisms influence erosive reflux esophagitis and gastritis in Taiwanese patients. J. Gastroenterol. Hepatol. 25: 1443-1451. http://dx.doi.org/10.1111/ j.1440-1746.2010.06310.x 
da Silva HD, da Silva AP, da Silva HA, Asano NM, et al. (2014). Interferon gamma and Interleukin 10 polymorphisms in Brazilian patients with systemic lupus erythematosus. Mol. Biol. Rep. 41: 2493-2500.http://dx.doi.org/10.1007/ $\underline{\text { s11033-014-3106-9 }}$

de-Madaria E, Martínez J, Sempere L, Lozano B, et al. (2008). Cytokine genotypes in acute pancreatitis: association with etiology, severity, and cytokine levels in blood. Pancreas 37: 295-301. http://dx.doi.org/10.1097/ MPA.0b013e31816726d5

Friedberg EC (2003). DNA damage and repair. Nature 421: 436-440.http://dx.doi.org/10.1038/nature01408

Gorelick FS and Thrower E (2009). The acinar cell and early pancreatitis responses. Clin. Gastroenterol. Hepatol. 7 (Suppl): S10-S14.http://dx.doi.org/10.1016/j.cgh.2009.07.036

Greer JB, Thrower E and Yadav D (2015). Epidemiologic and Mechanistic Associations Between Smoking and Pancreatitis. Curr. Treat. Options Gastroenterol. 13: 332-346. http://dx.doi.org/10.1007/s11938-015-0056-9

Gulla A, Evans BJ, Navenot JM, Pundzius J, et al. (2014). Heme oxygenase-1 gene promoter polymorphism is associated with the development of necrotizing acute pancreatitis. Pancreas 43: 1271-1276. http://dx.doi.org/10.1097/ MPA.0000000000000171

Krasnova TN, Samokhodskaia LM, Ivaninitskiı̌ LV, Korogodina AD, et al. (2015). [Impact of interleukin-10 and interleukin-28 gene polymorphisms on the development and course of lupus nephritis]. Ter. Arkh. 87: 40-44.

Lankisch PG, Blum T, Maisonneuve P and Lowenfels AB (2003). Severe acute pancreatitis: when to be concerned? Pancreatology 3: 102-110. http://dx.doi.org/10.1159/000070077

Li D, Li J, Wang L and Zhang Q (2015). Association between IL-1b, IL-8, and IL-10 polymorphisms and risk of acute pancreatitis. Genet. Mol. Res. 14: 6635-6641.http://dx.doi.org/10.4238/2015.June.18.6

Matas-Cobos AM, Redondo-Cerezo E, Alegría-Motte C, Martínez-Chamorro A, et al. (2015). The role of Toll-like receptor polymorphisms in acute pancreatitis occurrence and severity. Pancreas 44: 429-433.

Neoptolemos JP, Raraty M, Finch M and Sutton R (1998). Acute pancreatitis: the substantial human and financial costs. Gut 42: 886-891. http://dx.doi.org/10.1136/gut.42.6.886

Özhan G, Yanar HT, Ertekin C and Alpertunga B (2010). Polymorphisms in tumour necrosis factor alpha (TNFalpha) gene in patients with acute pancreatitis. Mediators Inflamm. 2010: 482950. http://dx.doi.org/10.1155/2010/482950

Pandol SJ, Saluja AK, Imrie CW and Banks PA (2007). Acute pancreatitis: bench to the bedside. Gastroenterology 132: 1127-1151.http://dx.doi.org/10.1053/j.gastro.2007.01.055

Pohl JF and Uc A (2015). Paediatric pancreatitis. Curr. Opin. Gastroenterol. 31: 380-386. http://dx.doi.org/10.1097/ MOG.0000000000000197

Sargen K, Demaine AG and Kingsnorth AN (2000). Cytokine gene polymorphisms in acute pancreatitis. JOP 1: 24-35.

Schneider A, Barmada MM, Slivka A, Martin JA, et al. (2004a). Analysis of tumor necrosis factor-alpha, transforming growth factor-beta 1 , interleukin-10, and interferon-gamma polymorphisms in patients with alcoholic chronic pancreatitis. Alcohol 32: 19-24. http://dx.doi.org/10.1016/j.alcohol.2003.09.006

Schneider A, Barmada MM, Slivka A, Martin JA, et al. (2004b). Transforming growth factor-beta1, interleukin-10 and interferon-gamma cytokine polymorphisms in patients with hereditary, familial and sporadic chronic pancreatitis. Pancreatology 4: 490-494. http://dx.doi.org/10.1159/000080245

Srivastava P, Shafiq N, Bhasin DK, Rana SS, et al. (2012). Differential expression of heat shock protein (HSP) 70-2 gene polymorphism in benign and malignant pancreatic disorders and its relationship with disease severity and complications. JOP 13: 414-419.

Sun J and Bhatia M (2007). Blockade of neurokinin-1 receptor attenuates CC and CXC chemokine production in experimental acute pancreatitis and associated lung injury. Am. J. Physiol. Gastrointest. Liver Physiol. 292: G143-G153. http://dx.doi.org/10.1152/ajpgi.00271.2006

Swaroop VS, Chari ST and Clain JE (2004). Severe acute pancreatitis. JAMA 291: 2865-2868. http://dx.doi.org/10.1001/ jama.291.23.2865

Talukdar R and Vege SS (2015). Acute pancreatitis. Curr. Opin. Gastroenterol. 31: 374-379. http://dx.doi.org/10.1097/ MOG.0000000000000201

Tun-Abraham ME, Obregón-Guerrero G, Romero-Espinoza L and Valencia-Jiménez J (2015). [Acute pancreatitis associated with hypercalcaemia]. Cir. Cir. 83: 227-231.http://dx.doi.org/10.1016/j.circir.2015.05.006

Yang HT, Wang SL, Yan LJ, Qian P, et al. (2015). Association of interleukin gene polymorphisms with the risk of coronary artery disease. Genet. Mol. Res. 14: 12489-12496. http://dx.doi.org/10.4238/2015.October.16.16

Yin YW, Sun QQ, Feng JQ, Hu AM, et al. (2013). Influence of interleukin gene polymorphisms on development of acute pancreatitis: a systematic review and meta-analysis. Mol. Biol. Rep. 40: 5931-5941. http://dx.doi.org/10.1007/ $\underline{\text { s11033-013-2700-6 }}$

Zhang DL, Zheng HM, Yu BJ, Jiang ZW, et al. (2005). Association of polymorphisms of IL and CD14 genes with acute severe pancreatitis and septic shock. World J. Gastroenterol. 11: 4409-4413. http://dx.doi.org/10.3748/wig. $\underline{\mathrm{v} 11 . \mathrm{i} 28.4409}$ 